\title{
Trees on farms: diversity, carbon pool and contribution to rural livelihoods in Kanchanpur District of Nepal
}

\begin{abstract}
S. K. Baral ${ }^{1 *}$, R. Malla ${ }^{1}$, S. Khanal ${ }^{1}$ and R. Shakya ${ }^{1}$
Trees and shrubs are important component of rural farming system in Nepal. This paper assesses tree diversity and carbon pool of trees and shrubs outside forests as well as their contribution in the rural economy of the study area. In the land use classification map derived from the high resolution ALOS Pan-sharpened imagery, random selection was made among systematic grid in the agriculture class to find out the inventory plot. The plot was designed as nested plot. Firstly, tree measurement was done and then leaves, branch samples as well as soil samples were collected from each sample plot. Structured questionnaire survey was used to assess the contribution of trees and shrubs on rural livelihoods. The biomass and soil samples were analyzed using dry combustion method to estimate the carbon content. The amount of carbon stock difference between farmland with TOF and without TOF was found $26.56 \mathrm{Mg}$ (megagram) ha-1. There was $350,714.6$ $\mathrm{Mg}$ above ground carbon, $35,103.36 \mathrm{Mg}$ root carbon and $84451.18 \mathrm{Mg}$ soil carbon accumulated by total trees and shrubs on farms in the District. Hence, the total carbon pool of the District in different agroforestry systems was estimated to be 470,269.18 Mg. Homegarden system was found to be a good agroforestry system in terms of having higher species richness, tree diversity and relatively higher amount of above and below ground carbon per unit area. The results also showed that the trees on farms contributed16.4\% (NRs. 3689 per household/year) and $17.1 \%$ (NRs. 2613 per household/year) of farmland income and livestock income respectively. The results, thus, indicate that trees on farms have visible impacts on rural livelihoods, harboring rich plant diversity and sequestering substantial amount of carbon.
\end{abstract}

Key words: Biomass, soil carbon, tree diversity, trees outside forest

$\mathrm{N}$ epal extends over an area of 147,181 sq. $\mathrm{km}$. in the lap of the central Himalayas in the South Asia. Geographically, Nepal is an extremely diverse country. It includes the flat plains of the Terai in the south and the sloping terrain of the Mid-hills and snowy mountains in the north (HMG/N, 2003). This diversity combines and interacts with factors such as social organization, religious belief and access to land and markets to give rise to a wide variety of farming systems and great variances within them (Mahat, 1987; Gibbon and Schultz, 1989; Thapa, 1994) which in turn has resulted in several agroforestry practices. Gilmour and Nurse (1991) mentioned that farmers planted fodder trees on the nearest farmland in Nepal. Likewise, a large number of multipurpose trees and shrubs are deliberately retained or incorporated on farms in the subsistence farming systems on the steep slopes in different parts of Nepal (Fonzen and Oberholzer, 1985). The farmers who cultivate land for crops production also raise livestock, and depend upon tree resources for the support of both components (Mahat, 1987; Thapa, 1994). Tree growing practices in and around homesteads, and on farmland has long been associated in rural areas of Nepal, and hence, considered as integral components of rural livelihoods (Oli, 2002). These tree resources are considered as trees outside forest (TOF) (GFRA, 2000). The contribution of these trees and shrubs has high potential for livelihood improvement (Regmi and Garforth, 2010). A study carried out by Kharal et al. (2008) found that the trees outside forest contain $3.3 \mathrm{~m}^{3} \mathrm{ha}^{-1}$ stem volume in Nawalparasi district of Nepal. On the other hand, socio-economic condition of the area affects farmland tree diversity (Kharal and Oli, 2008). Hence, there is a growing interest in assessing carbon sequestration potential and biodiversity of trees and shrubs on farms and its impact on rural livelihoods.

\footnotetext{
Department of Forest Research and Survey, Babarmahal, Kathmandu, Nepal

Corresponding author: sharadbaral@gmail.com
} 
Although the Nepalese tree resources outside forest can play a valuable role for enhancing sustainable development and people's livelihoods (Giri, 2004; FAO, 2002), the main focus has always been more on trees in forests that are viewed as a resource and a store of biological diversity. In addition, trees outside forests (trees grown on farmland, in and around homesteads and human settlements, in road and canal side and in other land use categories) have not been included in national forest inventory, even though they have diverse functions for wellbeing of humankind and in maintaining the natural environment (Oli, 2002). Therefore, this study attempts to assess the different agroforestry systems under TOF and their contribution on trees and shrub species diversity, rural livelihoods and climate change mitigation through carbon sequestration.

\section{Materials and methods}

\section{Study area}

Kanchanpur District lies in the far-western plain also known as Terai, and covers an area of 161,740 hectares. It stretches between $85^{\circ} 24^{\prime}-85^{\circ} 49^{\prime} \mathrm{E}$ longitudes and $28^{\circ} 23^{\prime}-29^{\circ} 8^{\prime} \mathrm{N}$ latitudes. The district is rich in forest resources occupying 88,200 ha (including rivers) of the entire district whereas the cultivated land occupies 59,532 ha (DDC, 2005). The altitude of the area varies from $54 \mathrm{~m}$ to $465 \mathrm{~m}$ above mean sea level. The general climate of the area is subtropical. The mean daily ambient temperature varied from $6.96^{\circ} \mathrm{C}$ to $43^{\circ} \mathrm{C}$; the mean annual temperature being $30.50^{\circ} \mathrm{C}$. The area received an average annual rainfall of 1,575 $\mathrm{mm}$. The relative humidity remains fairly high throughout the year except in the dry months of the pre-monsoon period. The terrain is almost flat, and is composed of alternate layers of clay and sand. Kanchanpur District is shown in figure 1.

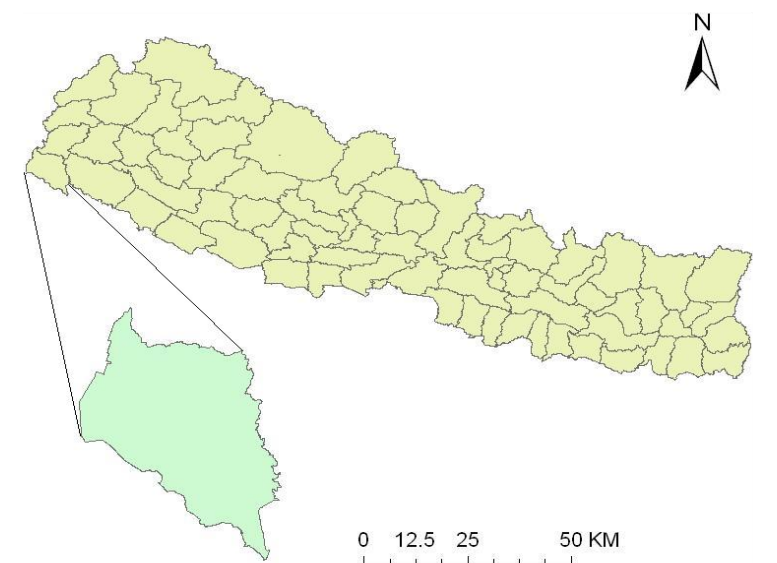

Fig. 1: Location of Kanchanpur District in the map of Nepal
A baseline study carried out by Paudel et al. (2008) in 6 Village Development Committees (VDCs) of Kanchanpur District showed that agriculture was the main occupation of the people (83\%). People used to make $85.3 \%$ of their income from agriculture. Only $61.9 \%$ of the people were food self-sufficient for a year round. Ninety nine per cent of the people possessed their own land and the average landholding per household was 27.3 kattha $\left(9,100 \mathrm{~m}^{2}\right)$. Agriculture was supported by livestock farming. Ninety six per cent of the household used to raise livestock and the average animal holding was 4.7 cattle equivalent. The main livestock rearing systems were grazing, stall feeding, and tethering. For stall feeding and tethering, people get fodder mainly (73\%) from their own land.

\section{Remote sensing data analysis and sample plot location}

For classifying landuse and obtaining agricultural area, satellite image (2007 ALOS Pan sharpened: $2.5 \mathrm{~m}$ ) from the Department of Forest Research and Survey (DFRS) archive was used.

Firstly, geometric correction and image enhancement was done. Then unsupervised classification supported by ground truthing was done in May, 2009. In the post classification, maximum likelihood method supported by field verification data and other secondary maps were used.

The accuracy assessment was carried out using error matrix. For this purpose 200 randomly placed points were generated by the software and compared with GPS (Global Positioning System) data from field, aerial photographs and topographic map. This gave the classification accuracy of $85 \%$. Topographic maps and aerial photographs and satellite imagery were used as secondary data.

\section{Sampling design}

Once the coverage of the area, which includes agricultural area and other land uses such as forest, river, sand and water bodies, was generated from the classified image; square shaped systematic grids of four square kilometers were overlaid on the area outside forest and each sample point (intersection point of the grid) was selected randomly using the frame sampling tools of Erdas Imagine 9.1 (Erdas, 2007; Erdas, 2008). Using 
the sample selection option, 45 sample plots $(25 \%)$ out of the total 181 plots were randomly selected in the study site; 15 plots within the areas having agri-silviculture practices, 6 plots within the areas covered by roadside plantation, 4 plots within the areas under silvo-pasture (private plantation) practices, and the rest 20 plots within home-gardens.

\section{Plot design}

The map showing the plot location as well as coordinate list of plots was printed for field visit. One hectare circular sample plots (radius $=56.4$ $\mathrm{m}$ ) were laid out in the field for measurement of tree height and diameter (at breast height, dbh). Five sub-plots of circular shape with $25 \mathrm{~m}^{2}$ (radius $=2.82 \mathrm{~m}$ ) size were established; four at the cardinal directions and one at the center for measurement of shrubs (Fig. 2). Within each subplot, one $1 \mathrm{~m} \times 1 \mathrm{~m}$ plot was established for herb measurement.

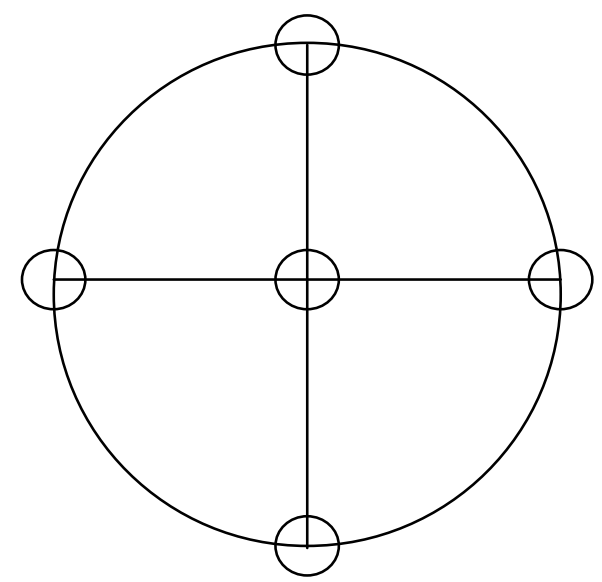

Fig. 2: Design of sample plots

\section{Tree measurement and soil sample collection}

Height (up to cm accuracy) and dbh (up to $\mathrm{mm}$ accuracy) of each tree and shrub present in the sample plots were measured using Suntoclinometer and Diameter Tape respectively. Soil samples were collected from the ground near the standing trees on the farms and the agriculture lands and also from the roadside plantation areas. Soil samples (200 gm) were collected from 0-10 $\mathrm{cm}$ and from 10-30 $\mathrm{cm}$ horizons from the $30 \mathrm{~cm}$ deep pits for chemical analysis. Besides, separate soil samples were collected using a sharp-edged Iron cylinder (height $5 \mathrm{~cm}$ and diameter $7 \mathrm{~cm}$ ) for bulk-density determination. The amount of litter present on the ground surface was estimated by collecting the same from each sub-plot using a
$30 \mathrm{~cm} \times 30 \mathrm{~cm}$ wooden-frame. For shrubs and other small undergrowths, destructive sampling was done. Biomass samples (leaves, timber, shrubs, herbs, and litter) as well as the soil samples were transported to the Soil Laboratory of DFRS for laboratory analysis of carbon content.

\section{Social survey}

Semistructured questionnaire was used to collect the socioeconomic impact of the farm trees on rural livelihoods. Other primary data were collected through field observation, field measurement, key informant's survey and using checklist. The secondary data were compiled from the District Profile and the Baseline Survey Report prerpared by Paudel et al. (2008).

\section{Data analysis}

The tree and shrub diversity was determined using species richness, basal area ratio, and occurrence of rare and endangered species. Tree diversity was calculated by using Shannon-Weiner index (equation 1). The higher number of species and more even distribution both increase diversity as measured by $H^{\prime}$. The high values of $H^{\prime}$ is representative of more diverse community. A community with only one species would have H' value of 0 , because Pi would be equal to 1 and be multiplied by log pi which would equal to zero. So the H' value allows us to know not only the number of species but also how the abundance of the species is distributed among all the species in the community (Magurran, 1988).

Shannon-Wiener index $\left(\mathrm{H}^{\prime}\right)=-\sum_{i=1}^{s} \dot{p}_{i} \times \log \dot{p}_{i}$

where, $s=$ number of species, and

$\mathrm{p}_{\mathrm{i}}=$ proportion of the $\mathrm{i}^{\text {th }}$ species in a community.

Soil bulk-density (SBD) was calculated by using the following equation:

SBD $\left(\mathrm{g} \mathrm{cm}^{-3}\right)=[$ dry soil mass $(\mathrm{g})-$ stone mass $(\mathrm{g})] /$ [dry soil volume $\left(\mathrm{cm}^{-3}\right)$ - stone volume $\left(\mathrm{cm}^{-3}\right)$ ] .. (2)

Above ground biomass, root biomass and carbon content were calculated using the following equations:

Dry wt. of tree biomass (AGB) $=$ $\mathrm{e}^{\left\{-3.141+.9719 \mathrm{Ln}\left(\mathrm{DBH}^{*} \mathrm{DBH}^{*} \mathrm{Ht} .\right)\right\}}$ (Brown et al., 1989)....(3) 
Root biomass $\left(\mathrm{Mg} \mathrm{ha}{ }^{-1}\right)=\mathrm{e}^{\{-1.0587+.8836 \operatorname{Ln}(\mathrm{AGB})\}}$ (Cairns et al., 1997)....

Carbon $=$ Biomass $\mathrm{x}$ carbon $\%$

\section{Laboratory analysis}

The carbon content of different biomass such as stems, branches, leaves and soil samples were analyzed in the Kathmandu University Laboratory. For this purpose, 250 grams of biomass samples were collected from the particular stems, branches and leaves. The samples were used for carbon content analysis after drying at $70^{\circ} \mathrm{C}$ to a constant weight. Soil bulk-density was determined by the core method. The soil organic carbon (SOC) concentration was determined using the dry combustion method using oven-dry soil samples as the method was recommended by IPCC (2003) for carbon project. The carbon content of the samples was analyzed and estimated using equation (5).

\section{Results and discussion}

\section{Landuse of Kanchanpur District}

The largest land use of the district is occupied by the forest $(48.49 \%)$ including protected area (PA) of the total area. Agricultural land occupies $39.32 \%$, grass/open land occupies $5.5 \%$ and the remaining area is occupied by sand/bolder, water and others (Table 1).

Table 1: Area occupied by different land uses

\begin{tabular}{clrr}
\hline S. N. & Land use & \multicolumn{1}{c}{ Area (ha) } & Area (\%) \\
\hline 1 & Forest & $78,341.23$ & 48.49 \\
2 & Shrub & $1,555.78$ & 0.96 \\
3 & $\begin{array}{l}\text { Grass and } \\
\text { open land }\end{array}$ & $8,888.54$ & 5.5 \\
4 & Agriculture & $63,592.86$ & 39.32 \\
5 & Sand/bolder & $4,917.21$ & 3.04 \\
6 & Water & $1,319.90$ & 0.82 \\
7 & Others & $3,096.91$ & 1.92 \\
\hline & Total & $\mathbf{1 6 1 , 7 1 2 . 4 3}$ & $\mathbf{1 0 0}$ \\
\hline
\end{tabular}

The total forest cover and other land uses were estimated using the Satellite data (ALOS Pan-sharpened) of 2007. The total forest cover of the District was reported to be $54 \%$ (88,000 ha) by Forest Resource Information System Project (FRISP) (1994) which was decreased to $48.5 \%$ in this study. This may be due to shrub and grassland area which was zero in the FRISP (1994) report; however, this study had indicated that $6.46 \%$ of the total land area of the District was occupied by shrub, grass and open land. From this fact, one could easily guess that about $6.5 \%$ of the forest land might have changed into shrub and grassland between 1994 and 2007 in the district. Larger part of agricultural land is distributed in southern part of the Churia (Siwaliks), near the Indian border (southern part of the District) and in Dodhara and Chandani VDCs.

\section{Socio-economic conditions of the people}

The total population of the district is 377,899 (DDC, 2005). Fifty households were randomly selected for socio-economic survey to get the information about impacts of farm trees on rural livelihoods. Of the total sampled respondents, $72 \%$ were male and $28 \%$ were female. Similarly, $87 \%$ were literate and the remaining $13 \%$ were illiterate.

\section{Occupation}

Majority of the people were dependent on both agricultural and non-agricultural activities for their livelihoods. Fifteen per cent of the population was found to be entirely dependent on agriculture while only $7 \%$ on non-agriculture.

\section{Food security}

The study found that the people had insufficient food production from their agricultural land because of low productivity and not having enough land to produce. Half of the people had sufficient amount of food available for yearlong and remaining half were under the food crisis. Twenty four households had enough land to produce food-grain for yearlong. However, the remaining 9, 10 and 7 households had the land that only can produce food grains for 6 to 12 months, 3 to 6 months and less than 3 months respectively.

\section{Livestock distribution}

This study reveals that livestock distribution was dominated by goats (39\%) and was followed by buffalo (31\%) and cow (30\%). Livestock farming was one of the important income sources for the people. 


\section{Different income sources}

Respondents were asked about their total and how the different income sources share the total. According to our field survey there were six types of major income sources. Out of six sources of income, income from crop and vegetable farming, income from services and income from livestock farming played vital role, which makes three fourth of the total income (Fig. 3).
Relative abundance of trees species on farmland

Dalbergia sissoo and Mangifera indica were the most abundant species planted on the farmland. Eucalyptus camaldulensis, Populus deltoides, Leucaena leucocephala, Trewia nudiflora, Syzygium cumini, Melia azedarach, Psidium guajava and Artocarpus lakoocha are the common tree species planted by the farmers (Fig. 5). Kharal et al. (2008) has also found

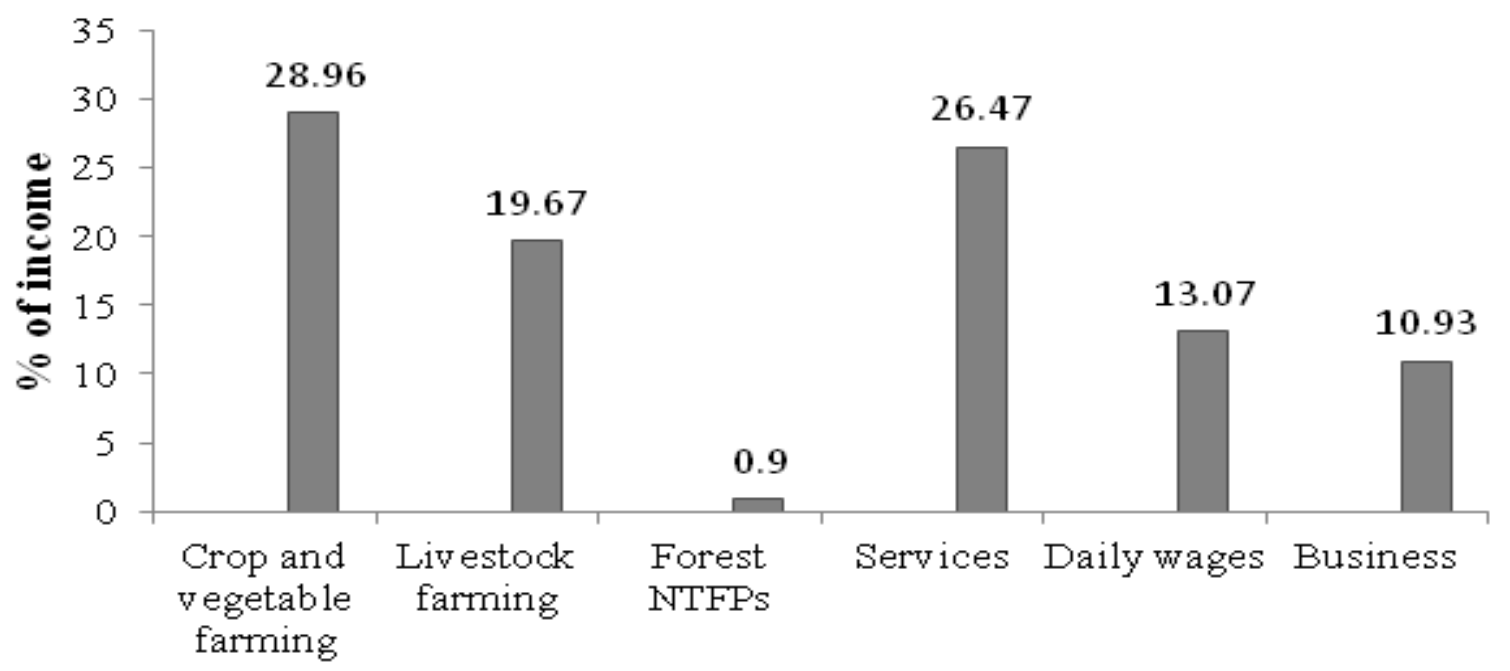

Fig. 3: Types of income sources and their share in total income

\section{Contribution of farmland tree on farmland and livestock income}

The average household income of the people in Kanchanpur District was NRs.78,002.00 (CBS, 2004). From our field survey, it was found that the farmland income and livestock income shared $28.8 \%$ and $19.5 \%$ respectively of the total household income (i.e. average annual household income of the people in Kanchanpur District). Similarly, farmland trees contribute $16.4 \%$ (NRs. 3,689.00 per household/year) and 17.1\% (NRs. 2613 per household/year) on farmland income and livestock income respectively (Fig. 4).

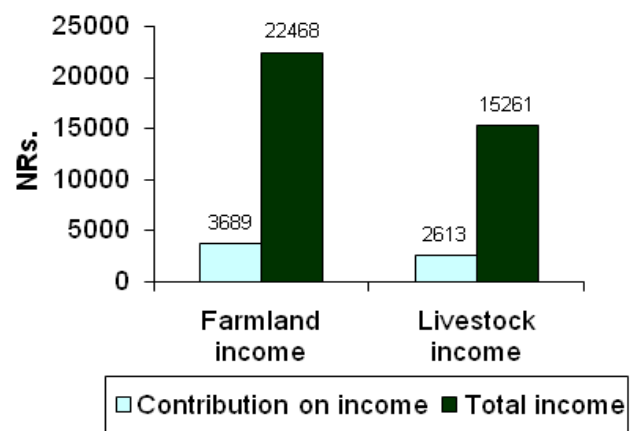

Fig. 4: Contribution of TOF on agriculture and livestock income
Dalbergia sissoo and Mangifera indica as the most abundant tree species in Nawalparasi District.

\section{Species richness, diversity index and biomass} of trees planted on farms

Area under TOF was grouped into four major tree planting systems such as homegarden, roadside plantation, private plantation and agrisilviculture. Species richness, tree diversity index and biomass per unit area were assessed among the systems. Homegarden system had the highest species richness, Shannon Weiner Index for tree diversity and higher biomass per unit area. Similarly, the Silvo-pasture (private plantation) had the highest biomass per unit area, but it had the lowest species richness and tree diversity index. Likewise, agrisilviculture system had relatively higher species richness but the lower Shannon Weiner index for tree diversity and biomass per unit area (Table 2). The wide individual distribution of the few tree species was the main reason for lower tree diversity index which is similar to Kharal and Oli (2008). This study showed average above and below ground biomass of TOF was 


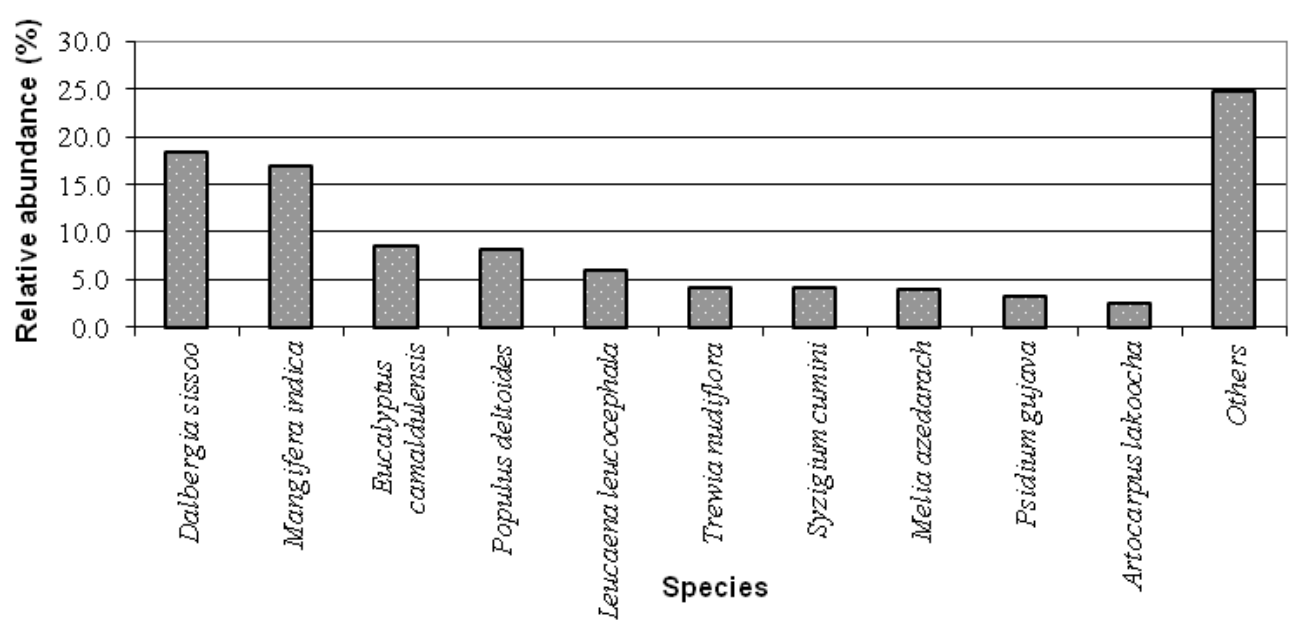

Fig. 5: Relative abundance of trees species on farmland

Table 2: Species richness, tree diversity and biomass of trees planted on farms

\begin{tabular}{llrrr}
\hline S. N. & Agroforestry system & $\begin{array}{c}\text { Species } \\
\text { richness }\end{array}$ & $\begin{array}{c}\text { Shannon } \\
\text { Weiner index }\end{array}$ & $\begin{array}{c}\text { Average above and below } \\
\text { ground biomass (dry wt. } \\
\text { kgha }^{-1} \text { ) }\end{array}$ \\
\hline 1 & Homegarden & 51 & 0.67 & 9092.167 \\
2 & Roadside plantation & 19 & 0.41 & 8411.826 \\
3 & $\begin{array}{l}\text { Silvo-pasture (private } \\
\text { plantation) }\end{array}$ & 3 & 0.13 & 11817.090 \\
4 & Agri-silviculture & 39 & 0.18 & 3293.801 \\
\hline
\end{tabular}

$8153 \mathrm{kgha}^{-1}$ which is similar to the findings of a study in Tanzania (Giri, 2004). Homegarden system and roadside plantation were the efficient agroforestry systems for maintaining higher tree diversity and higher biomass per unit area.

Soil orgainic carbon under different agroforestry systems/cultivation practices

Maintenance of biodiversity and carbon sequestration through the process of photosynthesis are two important and complementary environmental service functions of agro-ecosystems (Henry et al., 2009). In this study, SOC under different agroforestry systems were analyzed and compared separately, because it is an appealing option for sequestering carbon on agricultural lands and it can sequester significant amounts of carbon while leaving the bulk of the land in agricultural production (Schoeneberger, 2009). Homegarden system had higher SOC followed by roadside plantation and agri-silviculture system respectively (Table 3 ). In the upper layer of soil (0-10 cm soil depth) both homegarden and roadside plantation had the

Table 3: Soil organic carbon under different cultivation practices

\begin{tabular}{rlrrr}
\hline S.N. & Agroforestry system & Soil depth & Bulk density & SOC $\left(\mathbf{m g ~ g}^{-1}\right)$ \\
\hline \multirow{2}{*}{1} & \multirow{2}{*}{ Homegarden } & $0-10 \mathrm{~cm}$ & 1.09 & $18.85(1.7)$ \\
& & $10-30 \mathrm{~cm}$ & 1.17 & $12.57(1.8)$ \\
2 & \multirow{2}{*}{ Agri-silviculture } & $0-10 \mathrm{~cm}$ & 1.17 & $7.29(1.4)$ \\
& & $10-30 \mathrm{~cm}$ & 1.28 & $5.84(1.3)$ \\
3 & \multirow{2}{*}{ Roadside plantation } & $0-10 \mathrm{~cm}$ & 1.35 & $18.58(1.6)$ \\
& & $10-30 \mathrm{~cm}$ & 1.33 & $9.18(1.4)$ \\
\hline
\end{tabular}

Note: Standard errors of the corresponding values are presented in parentheses. 
same $\left(18 \mathrm{mgg}^{-1}\right)$ SOC however in deeper layer (10-30 cm soil depth), homegarden system had much higher amount $\left(12.57 \mathrm{mgg}^{-1}\right)$ of SOC.

Soil organic carbon stock down to $30 \mathrm{~cm}$ soil depth in agriculture land and the area occupied by trees on farms

SOC in agricultural land without tree (23.48 $\mathrm{Mg} \mathrm{ha}^{-1}$ ) was calculated and subtracted from the average amount of SOC (50.04 $\left.\mathrm{Mg} \mathrm{ha}^{-1}\right)$ under trees on farms to estimate the total amount of $\mathrm{C}$-sequestration per hectare in soil by trees on farms i.e. $26.56 \mathrm{Mg} \mathrm{ha}^{-1}$ (Table 4).

Table 4: Soil organic carbon stock up to $30 \mathrm{~cm}$ soil depth in agriculture land and the area occupied by trees on farms

\begin{tabular}{clr}
\hline S.N. & \multicolumn{1}{c}{ Landuse } & SOC $\mathbf{M g} / \mathbf{h a}^{-1}$ \\
\hline 1 & $\begin{array}{l}\text { SOC in agricultural } \\
\text { land without tree }\end{array}$ & 23.48 \\
2 & SOC in trees on farms & 50.04 \\
\hline C-sequestration in soil & $\mathbf{2 6 . 5 6}$ \\
\hline
\end{tabular}

Total soil organic carbon stock by farm trees and shrubs

It was estimated that the total trees and shrubs on farms in Kanchanpur District had sequestered 350,714.6 $\mathrm{mg}$ above ground carbon, $35,103.36 \mathrm{Mg}$ root carbon and 84,451.18 $\mathrm{mg}$ soil carbon $(0-30 \mathrm{~cm}$ soil depth). Hence, the total carbon pool in the trees outside forest in Kanchanpur District of Nepal was estimated to be 470,269.18 Mg (Table 5).

Table 5: Total soil organic carbon stock created by farm trees and shrubs

\begin{tabular}{rlrr}
\hline S. N. & Details & $\begin{array}{c}\text { Carbon } \\
\left.\text { (Mg ha }^{-1}\right)\end{array}$ & $\begin{array}{c}\text { Total carbon } \\
\text { stock (Mg) }\end{array}$ \\
\hline 1 & Above ground & 5.515 & $350,714.6$ \\
2 & Root & 0.552 & $35,103.26$ \\
3 & Soil carbon & 26.56 & $84,451.32$ \\
\hline & & Total & $\mathbf{4 7 0 , 2 6 9 . 1 8}$
\end{tabular}

Note: Area occupied by trees on farms $=3,179.643$ ha was calculated by measuring crown diameter of each tree.

Trees planted on farmland contribute 16 and
$17 \%$ to agricultural income and livestock income respectively. In addition, trees on farms have been recognized that it protects soil, water and biological diversity, provide shelter and shade for the local people. At the same time it contributes on climate change mitigation through carbon sequestration $\left(26.56 \mathrm{Mg} \mathrm{ha}^{-1}\right)$. Hence, the relationships of people, agriculture, and trees were found inseparably interlinked and interdependent. There is a tendency of choosing multipurpose tree species (legumes, fruits, fodder, timber and firewood) for planting trees outside the forest areas. This study recorded 51 species in homegarden system. Still the total number of species seems fairly low compared to the study in north-eastern India that recorded 197 species in homegarden (Tynsong and Tiwari, 2010). It indicates that there are lots of other species that could be suitable for TOF plantation (especially for agroforestry) for maintaining tree diversity and diversifying agroforestry products.

This study also found that people were very interested to plant several species in homegarden because diversity is the prime consideration for fodder and fruit species as people want to have fruits of different taste in different seasons (Kharal and Oli, 2008). However, they were very selective when they had to plant a tree species in the crop field (agri-silviculture). It reveals the fact that people are more sensitive on agricultural production while managing agri-silviculture. Moreover, the species diversity is less important for fuelwood and timber species (Kharal and Oli, 2008). Therefore, before planting a tree species in an agricultural field, they just want to be sure that the tree species will produce maximum benefits and minimum negative effects on the yield of cereal crops.

The high SOC under homegarden and roadside plantation than agri-silviculture shows that there is relatively less organic matter deposition in agriculture (Nair, 2009). SOC estimate in homegarden system is comparable to a study in western Kenya (Henry et al., 2009). Although, there was a positive relationship between tree diversity and carbon stocks (homegarden system), it was not a direct relationship. It just can be considered as an additive agro-ecosystem function. Carbon sequestration projects that contribute to enhance biodiversity should be considered as more accurate and secure in the long term than other large scale plantation projects. 
It, eventually, proves that TOF resources are inevitable part of life of the local people in Kanchanpur District. The role of TOF has been increasing in the present context i.e. for supporting livelihood of the local people, biodiversity conservation, carbon sequestration, combating desertification, and mitigating climate change etc. However, it is necessary to recognize its social, economical and ecological role.

\section{Conclusion}

Trees on farms have visible and significant impact on rural livelihoods of the people in Kanchanpur District. A wide diversity of tree species recorded shows that farmland are repository of high plant diversity as farm trees particularly in homegardens or scattered in and around homesteads. The trees contributed substantial amount of carbon storage. Potentials of agro-forestry, along with the continued progress in our scientific understanding, will be imperative if they are to be included in future formulations of national-level carbon trading and other natural resource management strategies. Therefore, further studies aiming at analyzing the feasibility of C-sequestration in farming systems focusing on the long-term resilience of C-storage and biodiversity, the potential for below ground $\mathrm{C}$-sequestration and social factors that may influence adoption of $\mathrm{C}$-sequestration practices by specifically designed sampling technique according to tree distribution pattern in the agroforestry systems are recommended.

\section{Acknowledgements}

The financial support for the study from the Livelihoods Forestry Programmeme (LFP), Baluwatar, Kathmandu is highly appreciated. We also acknowledge Mr. Yam Prasad Pokharel, Mr. Raj Kumar Giri and Mr. Devendra Lal Karna, DFRS for their company and support during the field work and Mr. Deepak Kharal, DFRS for his valuable comments in the manuscript.

\section{References}

Brown, S., Jellespie, A. J. R. and Lugo, A. E. 1989. Biomass estimation methods for tropical forest with applications to forest inventory data. Forest Science 35: 881-902.

Cairns, M. A., Brown, S., Helmer, E. H. and BauMgardner, G. A. 1997. Root biomass allocation in the world's upland forests. Oecologia 111: 1-11.

CBS. 2004. Nepal Living Standards Survey 2003/04. Statistical Report Volume One. Central Bureau of Statistics, Kathmandu, Nepal.

DDC. 2005. District Profile of Kanchanpur. District Development Committee, Kanchanpur, Nepal.

ERDAS. 2007. ERDAS IMAGINE Professional. Tour Guide. October 2007.

ERDAS. 2008. ERDAS Field Guide Volume Two. Leica Geosystems Geospatial Imaging, LLC.

FAO. 2002. Trees Outside Forests, A Key Factor in Integrated Urban and Rural Management. http://www.fao.org/DOCREP/ 005/Y2328E/y2328e05.htm Accessed on: 15th August 2009.

Fonzen, P. F. and Oberholzer, E. 1985. Use of multipurpose trees in hill farming systems in Western Nepal. Agroforestry Systems 2: 187-197.

FRISP. 1994. Forest and Shrub Cover of Nepal 1994 (1989-94). Forest Resource Information System Development Project, Forest Survey Division, Department of Forest Research and Survey, Kathmandu, Nepal.

GFRA. 2000. The Global Forest Resources Assessment 2000 - Main Report. FAO Forestry Paper 140. Rome. http://www.fao. org/forestry/site/7949/en/.htm Accessed on: 28th June 2009.

Giri, N. 2004. Assessment of tree resources outside forests: a lesson from Tanzania. Banko Janakari 14 (2):46-52.

Gilmour, D. A. and Nurse, M. 1991. Farmers' initiatives in increasing tree cover in central Nepal. Mountain Research and Development 11: 329-337.

Gibbon, D. and Schultz, M. 1989. Agricultural Systems in the Eastern Hills of Nepal: Present Situations and Opportunities for Innovative Research and Extension. PAC Technical Paper 108, Pakhribas Agricultural Center, Dhankuta, Nepal.

Henry, M., Tittonell, P., Manlay, R. J., Bernoux, M., Albrecht, A. and Vanlauwe, B. 2009. 
Biodiversity, carbon stocks and sequestration potential in above ground biomass in smallholder farming systems of western Kenya. Agriculture, Ecosystems, and Environment 129: 238-352.

HMG/N. 2003. Nepal Biodiversity Strategy. Ministry of Forests and Soil Conservation, Kathmandu, Nepal.

IPCC. 2003. Good Practice Guidance for Landuse, Landuse Change and Forestry. IPCC National Greenhouse Gas Inventories Programmeme Kanagawa (Japan): Institute for Global Environment Strategies.

Kharal, D. K., Giri, R. K. and Karna, D. L., 2008. Assessment of Trees Outside Forest: Nawalparasi District. Department of Forest Research and Survey, Kathamndu, Nepal.

Kharal, D. K. and Oli, B. N. 2008. An estimation of tree species diversity in rural farmland of Nepal. Banko Janakari 18 (1): 3-10.

Magurran, A. E. 1988. Ecological Diversity and its Measurement. Princeton University Press, Princeton, New Zealand.

Mahat, T. B. S. 1987. Forestry-Farming Linkages in the Mountains. Occasional Paper No. 7, ICIMOD, Kathmandu, Nepal.

Nair, P. K. R., Kumar, B. M. and Nair, V. D. 2009. Agroforestry as a strategy for carbon sequestration. Journal of Plant Nutrition and Soil Science 172: 10-23.
Oli, B. N. 2002. Trees outside forests: an ignored dimension of forest resource assessment. Banko Janakari 12 (1): 79-81.

Paudel, B., Maharjan, S. K., Rana, R. B., Shrestha, A., Shrestha, P., Basnet, A., Adhikari, A., Gurung, A., Regmi, B. R. and Sthapit, B. 2008. Findings of Baseline Survey on Socioeconomic and Agricultural Biodiversity of Western Terai Landscape Project of Nepal. Local Initiatives for Biodiversity, Research and Development, Pokhara, Nepal.

Schoeneberger, M. M. 2009. Agroforestry: working trees for sequestering carbon on agricultural lands. Agroforestry Systems 75: 27-37.

Thapa, B. 1994. Farmer's Ecological Knowledge about the Management and Use of Farmland Tree Fodder Resources in the Midhills of Eastern Nepal. Ph.D. Thesis, University of Wales, UK.

Tynsong, H. and Tiwari, B. K. 2010. Plant diversity in the homegardens and their significance in the livelihoods of War Khasi community of Meghalaya, North-east India. Journal of Biodiversity 1 (1):1-11. 